\title{
Analyzing Potato Market Participation, Market Surplus and Market Outlet Choice on Small Farm Household Level: the Case of Lemoworeda, Hadiya Zone, Southern Ethiopia.
}

Chaimiso Demisse Daniso ( $\square$ chaimisodemisse@gmail.com )

Arba Minch University https://orcid.org/0000-0002-3141-4981

Mebratu Alemu Sebeta

Arba Minch University

Afework Berihanu Shapa

Arba Minch Water Technology Institute: Arba Minch University

Mesfin Melese Abile

Wolkite University

Research

Keywords: Potato, Heckman second stage, Multivariate probit, Market channel

Posted Date: March 18th, 2021

DOI: https://doi.org/10.21203/rs.3.rs-310023/v1

License: (c) (1) This work is licensed under a Creative Commons Attribution 4.0 International License.

Read Full License 
Analyzing Potato market participation, market surplus and market outlet choice on small farm household level: the case of Lemoworeda, Hadiya zone, Southern Ethiopia.

Chaimiso Demisse1 Mebratu Alemu1* Afework Berihanu1* and Mesfin Melese1**

1=Lecturer at Arba Minch University, College of Agricultural Science, Agricultural economics, Arba Minch, Ethiopia $1 *=$ Lecturer at Arba Minch University, College of Business and Economics, Economics Department, Arba Minch, Ethiopia. 1**=Lecturer at Wolikite University, College of Agricultural Science, Agricultural economics, Wolkite, Ethiopia

\begin{abstract}
This study was aimed to analysis potato market participation, market surplus and market outlet choice in Lemo woreda of Hadiya zone southern Ethiopia. In this study, primary and secondary data source were employed. Data were obtained from a sample of 202 farm household. To take 202 sample farm household simple random sampling techniques were used. For data analysis, Heckman second stage and multivariate probit models were employed to identify factors that determine potato market participation decision and potato sale volume of the farm households, and potato farmer market outlet choice respectively. The Heckman's first stages (probit) indicates that education level, sex, membership in the cooperative, distance to the nearest market, remittent from family members, own transportation facilities, seed types, frequency of extension contact, lagged market price and amount of credit that farm household used for potato production determine potato market participation. Heckman the second stage (OLS) result shows that education level, cooperative membership, family size, total cropland, oxen owned, types of seed, and lagged market price were significantly determine potato marketed surplus. On the other side; the multivariate probit results showed that the probability of choosing wholesalers, retailers, collectors, and consumers market outlet choice significantly affected by age, educational level, sex, farm experiences, distance to near market, family size, remittance, land size, product supplied to the market, own transport facility and extension service. Based on the findings of the study, we recommend that the government and concerned stakeholders should focus on promoting improved potato seed, encouraging education, promoting farmers' cooperatives, empowering females, strengthening rural-urban infrastructure, and protecting informal labor trading.
\end{abstract}

Keywords: Potato; Heckman second stage; Multivariate probit; Market channel

\title{
1. Introduction
}

Potato (Solanumtuberosum L) commodity is one of the most leading vegetable crops in Ethiopia. Nutritionally, it is considered to be a well-balanced major plant food ranging from the macrocomponents to micro-nutrients. Because of its high yielding ability in a short season; the presence of suitable agro-ecological zones; the availability of labor for its production on large areas of land; and the accessibility of a potential market with considerable added value, potato is an important food and cash crop as income sources in Ethiopia (Yazie et al, 2017). It could play a key role in ensuring national food security in Ethiopia ((FAOSTAT, 2019; Gebru et al, 2017). 
Potato is a major root crop produced and most important sources of on-farm income for the farmers in Ethiopia (Endale et al., 2008). Potato and onion/shallot are the most commonly marketed vegetables accounting for about $60 \%$ and $20 \%$ of the marketed products. The other products such as 10 cabbage, beetroots, carrot, garlic, green pepper and tomato are marketed at relatively smaller quantities by few farmers' (Bezabih and Hadera, 2007). According to Belayneh, (2018), low value activities for potato take place at the farmers, brokers or wholesalers, retailers, and even consumer levels. Moreover, potato tubers crop has significant importance with the potential for domestic and export marketsand industrial processing. However, the production, marketing, and consumption of potatoes are restricted due to improper post-harvest handling. According to the report of (FAOSTAT, 2019; CSA, 2018; and Lemo district agriculture and rural development office (LDARDO), 2019)) the productivities' of potato was 13.8, 17.58, 19.93, and 21 tons per hectare in Ethiopia, SNNP Region, Hadiya zone, and Lemo woreda respectively. Though, according to Gebru et al. (2017) Potato is produced mostly for local consumption and the local market in Ethiopia.

\section{RESEARCH METHODOLOGY}

\subsection{Description of the Study Area}

The study was carried out in Lemo district, Southern Ethiopia. Its capital city is Hossana, located at about 232 kilometers from Addis Abeba to the south on the road running from Addis Abeba to Wolayta Sodo and 208 kilometers away from Hawassa, the capital city of Southern Nations, Nationalities, and Peoples Regional State. The Woreda lies between $7^{\circ} .14^{\prime}$ to $7^{\circ} .45^{\prime}$ North Latitude and $37^{\circ} .05^{\prime}$ to $37^{\circ} .50^{\prime}$ East Longitude with an altitude range of $1990-2720$ m.a.s.l. The mean annual rainfall varies between $700 \mathrm{~mm}$ to $1226 \mathrm{~mm}$, and the mean annual temperature varies between $15^{\circ} \mathrm{C}$ and $20^{\circ} \mathrm{C}$. It is bordered by Silte Zone in the North, Kembata Tembaro Zone in the South, Gombora Woreda of Hadiyya Zone in the North West, Ana Lemo Woreda of Hadiyya Zone in the North East and Shashogo Woreda of Hadiyya Zone in the East.

The household heads in the study area were 20533. The district is classified into two climatic zones: Dega or the highland (16.7\%), Weina Dega, or midland $(83.3 \%)$. The soil type of the area is loam soil. The area has been identified as having great agriculture and market potential, and the farmers' in the area are smallholders and the field is also prepared manually with the help of oxen power. Farms are mixed in terms of crops and livestock. Major root crop components of the area are covered by potatoes.

\subsection{Data Type, Sources, and Methods of Data Collection}

For this study, both quantitative and qualitative types of data were employed. To collect those data both primary and secondary data sources were employed. Primary data was collected from potato value chain actors. Secondary data sources were reviewed through reviewing different works of literature such as books, journals, thesis (different research reports), different unpublished organizational reports and documents, website information, and CSA which are found relevant for the study. Primary data was collected from sample representatives' by 
recruited enumerators; who were fulfilled minimum requirements like familiar with the study area, translate the English language to local and those collectorswere trained about the objectives of the study with the supervision of the researcher. Focus Group Discussion (FGD) by using checklists was also used to collect data to support survey data and other information that not collected during individual interviews. The focus group discussion member were conducted from each sample kebeles, deep interview was conduct to cross-check the collected data.

\subsection{Sample Size and Sampling Procedures}

To take 202 potato producers' sample respondents, simple random technuique was employed By using that list, 202 households were selected for the survey by using formula. That means, in the study area, the total household head number was 20,533 from those 202 household heads sample size was determined. To determine the sample size of potato producers/farmers for this study, Yamane's, (1967) formula was employ.

$$
n=\frac{\mathbf{N}}{\mathbf{1}+\mathbf{N}\left(\mathbf{e}^{2)}\right.}
$$

$\mathbf{n}=\frac{20533}{1+20533(0.07)^{2}}=202$

Where: $\mathrm{n}=\mathrm{is}$ the sample size $\mathrm{N}=$ is the total Potato producer households in selected kebeles e=is the level of precision (0.07)

Finally, proportional to population size was employed to select the sample households from each kebeles were selected.

\subsection{Methods of Data Analysis}

In this study both descriptive and econometric analysis were employed to data analysis. descriptive statistics such as frequencies, percentages, means,t-test, Ch2-test,and standard deviations were used to analyze the collected data.

\subsubsection{Factors affecting market participation and the marketed surplus of Potato}

To identify factors affecting market participation and the marketed surplus of Potato products in the study area, Heckman's sample selection model was used. In the first stage, the Heckman model attempts to capture participation decisions. This equation is used to construct a selectivity term known as the "Inverse Mills Ratio" which is added to the second stage outcome equation that explains factors affecting the quantity of marketed surplus. The inverse Mill's ratio is a variable which is used to control bias due to sample selection (Heckman, 1979). The second stage involves including the Mills ratio to the quantity of marketed surplus equation and estimating the equation using Ordinary Least Squares (OLS). If the mill's ratio is significant in the model there are some unobserved variables in the participation equation is confirmed. After the inclusion of this extra term (lambda), the coefficient in the second stage selectivity corrected 
equation is unbiased (Zaman, 2001). Specification of the Heckman two-step, which is written in terms of the probability of potato product producer's market participation (Y1i), and marketed surplus (Y2i),

The participation/ binary probit model is specified as:

$$
\begin{gathered}
Y_{1 i}=\boldsymbol{X}_{1 i} \boldsymbol{\beta}_{1 i}+\boldsymbol{u}_{1 i} u \sim \mathbf{N}(\mathbf{0}, \mathbf{1}) \\
\mathrm{PMP}=1 \text { if } \mathrm{Y}>0 \\
\mathrm{PMP}=0 \text { if } \mathrm{Y} \leq 0
\end{gathered}
$$

Where: $Y 1 i$ is the latent dependent variable, which is not observed; $X 1 i$ is vectors that are assumed to affect the probability of sampled household potato market participation; $B 1 i$ is a vector of an unknown parameter in the participation equation, and $U 1$ are residuals that are independently and normally distributed with zero mean and constant variance

\section{The observation equation/the marketed surplus equation}

$$
Y_{2 i}=X_{2 i} \beta_{2 i}+\mu_{i} \lambda_{i}+\eta_{i}
$$

Where: $Y 1 i$ is the latent dependent variable, which is not observed; $X 1 i$ is vectors that are assumed to affect the probability of sampled household potato market participation; $B 1 i$ is a vector of an unknown parameter in the participation equation, and $\mathrm{U} 1$ are residuals that are independently and normally distributed with zero mean and constant variance

$$
\lambda \mathbf{i}=\left(f\left(X_{1} \boldsymbol{\beta}_{\mathbf{1}}\right)\right) /\left(\mathbf{1}-f\left(X_{\mathbf{1}} \boldsymbol{\beta}_{\mathbf{1}}\right)\right)
$$

$f(X \beta)$ is a density function and $1-\mathrm{f}(X i \beta i)$ is a distribution function

$$
\begin{aligned}
\mathrm{Y} 2 \mathrm{i}=\beta 0+\beta 1 & \text { Age }+\beta 2 \text { Education }+\beta 3 \text { SEX }+\beta 4 \text { COOPMR }+\beta 5 \text { DNMARKET }+\beta 6 \text { Adultequ } \\
& +\beta 7 \text { ERetance }+\beta 8 \text { FSIZE }+\beta 9 \text { transport }+\beta 10 \text { oxen }+\beta 11 \text { Seed } \\
& +\beta 12 \text { EXTANTION }+\beta 13 \text { LPRICE }+\beta 14 \text { ACREDIT }+\mu \mathrm{i} \lambda \mathrm{i}+\eta
\end{aligned}
$$

Before fitting important variables into the Heckman two-stage selection model it is necessary to test was checked.

\subsubsection{Econometrics model for the determinants of potato marketing outlet choice}

Producers' decisions to participate in a given market derived from the maximization of expected utility from these markets and help to reduce some risks than a single market channel (Arinloyeet al., 2015). Econometric models such as multivariate probit/logit and multinomial probit/logit are useful models for the analysis of categorical choice dependent variables. Multinomial models are appropriate when individuals can choose only one outcome from among the set of mutually exclusive and collectively exhaustive alternatives. However, in the study area, there are several market outlets (wholesalers, Collectors, Retailers, and consumers) and farmers can select more than one outlet simultaneously to maximize the expected utility and due to this there are some overlapping and many farmers sell to more than one market outlets. So, the study adopted the 
multivariate probit (MVP) econometric technique to simultaneously model the influence of the set of explanatory variables on each of the different market channel choices, while allowing the unobserved and/or unmeasured factors (error terms) to be freely correlated as well as the relationships between the choices of different market outlets (Greene, 2012).

The observed outcome of market channel choice can be modeled following random utility formulation. Consider the $i^{\text {th }}$ farm household $(\mathrm{i}=1,2,3 \ldots \mathrm{N})$, facing a decision problem on whether or not to choose the available market Let $\mathrm{U}_{\mathrm{k}}$ represents the benefits of farmers to choose the mth market outlet where $m$ denotes the choice of wholesaler $\left(\mathrm{Y}_{1}\right)$, Retailer $\left(\mathrm{Y}_{2}\right)$, collector $\left(\mathrm{Y}_{3}\right)$, and consumer $\left(\mathrm{Y}_{4}\right)$. The producer decided to choose the $\mathrm{m}^{\text {th }}$ market outlet if, $Y^{*}=U k^{*}$ $U 0>0$. The net benefit $\left(\mathrm{Y}_{\mathrm{im}}{ }^{*}\right)$ that the farmer derives from choosing a market outlet is a latent variable determined by observed explanatory variable $(\mathrm{Xi})$ and the error term $(\varepsilon)$ :

$$
\text { Yim }=\text { BimXim }+\operatorname{cimYim}=\left\{\begin{array}{c}
1, \text { if } y>0 \\
0, \text { Otherwise }
\end{array}\right.
$$

Where $Y_{i m}(m=1,2, \ldots .5)$ denotes the market outlet choices, $\left(Y_{1}\right)$ for wholesaler, $\left(Y_{2}\right)$ for Retailer, $\left(\mathrm{Y}_{3}\right)$ for the collector, $\left(\mathrm{Y}_{4}\right)$ and for the consumer (available for $\mathrm{i}^{\text {th }}$ potato producer, $(\mathrm{i}=$ $1 . . . . \mathrm{n})$; Xim is a vector of explanatory variables, $\beta_{\mathrm{im}}$ denotes the vector of parameters to be estimated, and $\varepsilon_{\mathrm{im}}$ are random error terms distributed as a multivariate normal distribution with zero mean and variance-covariance matrix $\mathrm{V}$.

\section{Results and Discussions}

\subsection{Characteristics of the sample respondents}

The survey result indicates that out of a total of 202 sampled farm households, 156 household heads were product producers as well as market participants for potato remain 46 households were potato producers but non-market participants.

Table 1 show that there was a significant mean difference between market participants and nonparticipants among continuous variables Educational level, Distance to the nearest market, Adult equivalent, Total cropland have, Oxen owned by a farmer, Extension contact and Amount of credit used.

Table1: Two- group mean comparison test of continuous variables

\begin{tabular}{|c|c|c|c|c|}
\hline Variable & & Mean & & t-value \\
\hline & $\begin{array}{l}\text { Nonparticipant } \\
\text { s }(\mathrm{N}=46)\end{array}$ & $\begin{array}{l}\text { participants } \\
(\mathrm{N}=156)\end{array}$ & $\begin{array}{l}\text { Total }(\mathrm{N}=202) \mathrm{C} \\
\text { ombined mean }\end{array}$ & \\
\hline Age of household head & 48.61 & 47.33 & 47.62 & 0.699 \\
\hline Educational level & 2.087 & 7.481 & 6.252 & $-10.440 * * *$ \\
\hline
\end{tabular}




\begin{tabular}{lcccc}
\hline Distance to the nearest market & 72.152 & 43.628 & 50.124 & $7.737^{* * * *}$ \\
Adult equivalent & 4.489 & 5.455 & 5.235 & $-3.036^{* * *}$ \\
Total cropland have & .832 & 1.508 & 1.354 & $-5.666^{* * *}$ \\
Oxen owned by a farmer & 1 & 2.135 & 1.876 & $-7.331^{* * *}$ \\
Extension contact & .565 & 2.365 & 1.955 & $-10.966^{* * *}$ \\
Amount of credit used & 0 & 1728.205 & 1334.653 & $-2.533^{* *}$ \\
\hline
\end{tabular}

Note: $* * *$ and $* *$ shows significance at 1 , and 5 respectively.

Source: own computation from the survey result, 2020

In table 2 Chi-square test result revealed that there was a statistically significant proportion difference between market participants and non-participants in terms of sex, being a member of the cooperative, remittance, Own transportation facilities, types of seed they used, and lagged market price.

Table 2Two- group mean comparison test of dummy variables

\begin{tabular}{|c|c|c|c|c|}
\hline Variable & Categories & $\begin{array}{c}\text { Non- } \\
\text { participant(46) }\end{array}$ & Participant(156) & $\chi^{2}$ \\
\hline \multirow{2}{*}{$\begin{array}{l}\text { Sex of household } \\
\text { head }\end{array}$} & Male & $34(74 \%)$ & $141(90.38 \%)$ & \multirow[b]{2}{*}{$8.32 * * *$} \\
\hline & Female & $12(26 \%)$ & $15(9.62 \%)$ & \\
\hline \multirow{2}{*}{$\begin{array}{l}\text { Member of } \\
\text { Cooperative }\end{array}$} & Yes & $2(4.35 \%)$ & $34(21.8 \%)$ & \multirow[b]{2}{*}{$7.38 * * *$} \\
\hline & No & $44(95.65 \%)$ & $122(78.2 \%)$ & \\
\hline \multirow{2}{*}{$\begin{array}{l}\text { Effect of } \\
\text { remittances }\end{array}$} & Yes & $17(37 \%)$ & $108(67.23 \%)$ & \multirow[b]{2}{*}{$15.69 * * *$} \\
\hline & No & $29(63 \%)$ & $48(32.77 \%)$ & \\
\hline \multirow{2}{*}{$\begin{array}{l}\text { Own transportation } \\
\text { facilities }\end{array}$} & Yes & $10(21.74 \%)$ & $120(77 \%)$ & \multirow[b]{2}{*}{$47.16^{* * *}$} \\
\hline & No & $36(78.26 \%)$ & $36(23 \%)$ & \\
\hline \multirow{2}{*}{$\begin{array}{l}\text { Types of seed they } \\
\text { used }\end{array}$} & Improved & $4(8.70 \%)$ & $126(80.77 \%)$ & \multirow[b]{2}{*}{$80.45^{* * *}$} \\
\hline & Local & $42(91.30 \%)$ & $30(19.23 \%)$ & \\
\hline
\end{tabular}




\begin{tabular}{lcccc}
\hline $\begin{array}{l}\text { Lagged market } \\
\text { price }\end{array}$ & Good & $5(2.17 \%)$ & $64(41.03 \%)$ & \\
& Bad & $41(89.13 \%)$ & $92(58.97 \%)$ & $14.36^{* * *}$ \\
\hline
\end{tabular}

Note: $* * *$ shows significance at $1 \%$ level.

Source: own computation from the survey result, 2020

\subsection{Determinants of market participation decision and marketed surplus}

Potato products are produced for both market and household consumptions in the study area. Social, economic, institutional, and demographic variables are assumed to determine potato product market participation and marketed surplus by sampled potato producer households.

Heckman's selection model was employed to identify market participation and marketed surplus. Before running the model Heckman two-stage models, the hypnotized predicted variables were checked for the existence of a multicollinearity problem. The computed values of VIF and CC were found to be very low compared to their respective critical values $(<10$ for VIF and $<0.75$ for $\mathrm{CC}$ ), which revealed the absence of a severe multicollinearity problem among these potential explanatory variables.

The variables were also checked for the presence of heteroskedasticity in the data by using Breusch-pagan/Cook-Weisberg (chi2 $(1)=97.75$; prob> chi2 $=0.00$ ) and the test result shows that there was a heteroskedasticity problem. This problem can be overcome by using robust Heckman two stages results; for model result interpretation robust results were employed.

\subsubsection{Determinants of potato market participation}

In the first stage of Heckman, the household decides whether they would be a potato seller or not. The decision to participate in the potato market was estimated by a robust first-stage Heckman estimator. Fourteen potential predictor variables (six dummy and eight continuous) were selected and entered into Heckman's first stage model. The results of the study indicate that the Wald test of the hypothesis that all regression coefficients are jointly equal to zero is rejected at the $1 \%$ significance level in potato. This test result shows that, jointly, the independent variables included in the probit regression model explain the variations in a household's probability to sell potato.

The educational level of household head: Educational level of the household head had a positive and significant effect on market participation decisions at a $1 \%$ significance level. This might be due to educated households that may calculate the cost and benefit based on the market price trend. In the study area, the price trends are increasing for potatoes from time to time; on that trend, more educated household heads are more participants in the market. This finding parallel with Ahmed et al, (2016) educational level affects potato market participation positively and significantly. 
Sex of household head: The sex of the household head had a negative and significant effect on potato market participation decision at a $1 \%$ significant level. In the study area family, livelihood obligations might be common for both sex household heads but male household heads have more capability to get additional income than female household heads to pay those expenses. For that reason, female household heads are more market participants than male household heads. This result is in line with the result of Nuri, (2016) being a male household head was found to exert a negative impact on Koch and bulla market participation.

Membership in Cooperative: As was expected, this variable had a positive relation with household head potato market participation decision, and it was found to be statistically significant at a 5\% level. Being a member of the cooperative motivates farmers to participate in the market through networking and the provision of up-to-date information to members. This finding in line with findings by Mohammed, (2017) who finds that being a cooperative member can affect the women in market participation for soybean positively.

Distance to the nearest market: As was expected, market distance had been negatively and significantly associated with the household head participating in the potato market and statistically significant at $1 \%$. The closer the market the lesser would be the transportation charges, reduced walking time, and reduced other marketing costs, better to access market information and facilities. This result in line with the result of Regasa, (2018) revealed that distance to the market affects the supply of wheat by smallholders in Ethiopia revealed negatively.

Effect of remittances: As it was expected, it had been positively and significantly associated with the household head to participate in the potato market and statistically significant at $5 \%$. According to kebeles' key informant interview, household head remittent were more market participants than other remittent family members after he/she comes back. The reason for this was they are more aware of technology transfer with additional income. This result in line with Seng, (2016) non-farm income from remittance exhibited positive effects on farmer market participation on Farm Households' Food Security.

Own transport facility: It was similar to prior expectation own transport facility for household heads had positive and significant effects on potato market participation decision at $1 \%$. The finding corroborates that of Efa, et al (2016) who found that in determinants of market participation and intensity of marketed surplus of teff producers in Bacho and Dawo districts of Oromia State, Ethiopia, own transport facility affects teff market participation significantly and positively.

Types of seed they used: Types of seed that farm household head used had positive and significant effects on household head potato market participation decision at a $1 \%$ significant level. Using improved seed varieties was associated with a high productivity level than that of local varieties. If there is a highly productive yield this leads to more market participation. This result confirms with findings by Alamerie, (2016) improved potato seed affects the probability of the potato market participation positively. 
The number of extension visits: It had been a significant and positive effect on the household head farmers' market participation decision at a 5\% significant level. This could be attributed to the fact that an increase in the number of extension visits would avail up-to-date information regarding agricultural technologies that might improve productivity and therefore it increase the probability of market participation. This study similar to the study was undertaken by Christopher et al., (2014) indicated that the number of extension visits from government workers had a positive and significant effect on the decision to participate in the market.

Lagged market price: Lagged market price had a positive and significant effect on market participation decisions at a 5\% significance level. Most of the time farm household heads expect that if the last year's price for potato products was good the probability for potato market participation is the increase this year. This result was similar to the result found by Tadie and Lemma, (2018), the lagged market price has a positive and significantly affects teff market participation.

Amount of credit used: As expected; the amount of credit used by farm household heads was positively and significantly influences the likelihood of farmers in market participation at less than a $1 \%$ significance level. The findings of Abduselamet al, (2018) hinted that access to credit had a positive and significant impact on producers' likelihood to participate in the potato market because the availability of credit reduces transaction costs of both input and output markets.

Table 3 First-stage probit estimation after robust results of the determinants of potato market participation

\begin{tabular}{lllll}
\hline \multicolumn{1}{c}{ Variable } & Coefficient & $\begin{array}{c}\text { Robust Stand } \\
\text { error }\end{array}$ & Z & $\begin{array}{c}\text { Marginal } \\
\text { effect }\end{array}$ \\
\hline Age of household head & -.0045 & .0191 & -0.23 & -.0003 \\
The education level of the household head & .2795 & .0671 & 3.08 & $.0203^{* * *}$ \\
Sex of household head & -1.736 & .8457 & -2.65 & $-.1262^{* * *}$ \\
Member of Cooparetive & 1.075 & .5814 & 2.43 & $.0781^{* * *}$ \\
Distance to the nearest market & -.0251 & .0067 & -8.88 & $-.0018^{* * *}$ \\
Adult equivalent & .0182 & .0809 & 0.22 & .0013 \\
Effect of remittances & .6966 & .4864 & 2.01 & $.0506^{* * *}$ \\
Total cropland have & -.3492 & .4125 & -0.81 & -.0254 \\
Own transportation facilities & 1.932 & .6873 & 2.72 & $.1405^{* * * *}$ \\
Oxen owned by a farmer (oxen) & -.0363 & -.3396 & -0.11 & -.0026 \\
Types of seed they used & 1.327 & .3852 & 3.91 & $.0965^{* * *}$ \\
Frequency of extension contact & .6419 & .4012 & 2.26 & $.0467^{* * *}$ \\
\hline
\end{tabular}




\begin{tabular}{lllll}
\hline Lagged market price & 1.474 & .5466 & 2.37 & $.1071^{* *}$ \\
Amount of credit used & .0117 & .0002 & 3.92 & $.0008 * * *$ \\
Constant & $-2.791 * * *$ & .7650 & -3.65 & \\
\hline Number of obs & & & 202 & $158.10 * * *$ \\
\hline Wald chi2(13) & & & \\
Note: ***,** and * shows significance at 1,5 and 10\% respectively. & & & \\
\hline
\end{tabular}

Source: own computation from the survey result, 2020

\subsubsection{Determinants of potato marketed surplus}

Heckman's second stage estimation identifies the significant factors that determine potato marketed surplus by using the selection model which included the inverse Mill's ratio calculated from a maximum likelihood probit estimation of potato market participation decision. The coefficient of the Inverse Mills ratio (Lambda) in the Heckman two-stage estimation is significant at the $1 \%$ probability level (Table 4 ). This indicates the existence of sample selection bias, which is the existence of some unobservable farmer characteristics determining farmer's likelihood to participate in the potato market and thereby affecting the extent of marketed surplus. And, the positive sign of the inverse mill's ratio shows that there are unobserved factors that are positively affecting both participation decision and marketed potato volume. Rho $(\rho)$ is the correlation between the error terms of the substantive and selection models. Rho features a potential range between -1 and +1 and might give some indication of the likely range of selection bias. A correlation with a definite quantity of 1 would occur if the regression coefficients of the selection model and also the regression coefficients of the substantive model were estimated by identical processes (i.e., potential selection bias). The overall goodness of fit of the model parameter estimates is assessed based on the wald-ch2 test. The null hypothesis for the wald-ch2 test is that all coefficients are jointly zero. The chi-square test result indicates the overall goodness of fit of the. A total of thirteen potential predictor variables (six dummy and seven continuous) were selected and entered into the Heckman 2nd stage model. To examine what factors determine the sampled household's marketed surplus of potato in the study area 2nd stage Heckman model after robust was used because there was a heteroscedasticity problem. From those explanatory variables; the education level of the household head, being a membership on Cooperative, family size, total cropland have, oxen owned by a farmer, types of seed they used, and lagged market are significantly determined potato marketed surplus.

The education level of household head: As expected, education of household had been positively and statistically significant at less than $1 \%$ level of significance. As the sample household head education status increases by a unit year, the quantity of potato supplied to the market increases by $1.71 \mathrm{Qt}$. This suggests that the educated household head highly potato suppliers to the market the reason is that educated farmers have more knowledge and experience 
that allow them to interpret information about the market. This study in line with Bakala \& Tadesse, (2019) who found the educational level of the household head affects the potato market supply positively.

Being a membership in a Cooperative: The survey result shows that, being membership in a potato cooperative had been a positive and significant effect on household potato marketed surplus at a $1 \%$ significant level. Cooperative members get well-updated information, improved seed, and different direct and indirect supports from cooperatives. This makes farmers enable to produce more products and supply to the market. The Heckman $2^{\text {nd }}$ stage shows that if a farm household head is a member of any potato cooperative, the quantity of potato that is marketed in the market increased by $12.36 \mathrm{Qt}$, making other things constant. This finding in line with Bekeleet al., (2017) they found that being cooperative membership affects potato market supply positively and significantly.

Family size (adult equivalent): Family size affects the potato market surplus positively and significantly at less than a $10 \%$ significant level. It was opposite to prior expectations. The survey result indicates that as family size in adult equivalent increases by one unit the potato marketed surplus increase by $1.96 \mathrm{Qt}$, making other things constant. When farm household head has a high family size they used their labor on income generation by that generated income they might rent additional land and other inputs to produce a high amount of potato products. Which leads to a high amount of potato supplied to the market. These findings relate with findings by Mohammed, (2017) who founds family size positively affect the supply of soybean by women farmers

Total croplands that had for farm household head: As it was hypothesized, the size of landholding positively and significantly level influences the volume of potato marketed surplus at less than $1 \%$ probability. As the area of landholding by farmers increased by one hectare, the quantity of potato marketed surplus would increase by 13.67Qt. This confirmed with the sultan, (2016) indicated that a unit increase in land allocated for wheat would give rise to an increase in the amount of wheat supplied to the market. This finding also relates to Abdullah et al, (2019) Household farm size exhibited positive effects on farmers' participates in commercialization.

Oxen owned by a farm household head: As expected, the number of oxen that have for the household head was positively and significantly affects the marketed surplus of potato at a $1 \%$ significant level in a study area. The result shows that all things make constant, as oxen owned for farm household head increased by one marketed surplus for potato products increased by 13.82Qt. This deep-rooted with Habtamu, (2015) found that the number of oxen owned by households had a positive and significant effect on the potato marketed surplus.

Types of seed that farm household head used: The use of improved seed varieties had positive and significant effects on potato marketed surplus at less than $1 \%$ significant level. The survey result reveals that if the seed of the potato is improved one the potato supplied to the market is 
increased by $8.51 \mathrm{Q}$, making other things constant. Abduselam et al, (2018) found that access to improved seed influence the amount of potato marketed surplus positively and significantly.

Table4 Results of the robust second-stage Heckman selection model for potato market surplus.

\begin{tabular}{|c|c|c|c|}
\hline Variable & Coefficient & Stand error & $\mathbf{Z}$ \\
\hline Age of household head & -.0420 & .179 & -0.23 \\
\hline Education level of household head & $1.714 * * *$ & .534 & 3.21 \\
\hline Sex of household head & 1.446 & 5.139 & 0.28 \\
\hline Member of Cooparetive & $12.356 * * *$ & 4.628 & 2.67 \\
\hline Distance to the nearest market & -.082 & .055 & -1.49 \\
\hline Adult equivalent & $1.957 *$ & 1.015 & 1.93 \\
\hline Effect of remittances & -3.890 & 3.565 & -1.09 \\
\hline Total crop land have & $13.667 * * *$ & 13.667 & 3.56 \\
\hline Own transportation facilities & 1.199 & 3.093 & 0.39 \\
\hline Oxen owned by a farmer (oxen) & $13.821 * * *$ & 3.735 & 3.70 \\
\hline Types of seed they used & $8.514 * * *$ & 3.237 & 2.63 \\
\hline Frequency of extension contact & 1.439 & 1.507 & 0.96 \\
\hline Lagged market price & $13.110 * * *$ & 4.127 & 3.18 \\
\hline Constant & $-61.998 * * *$ & -14.447 & -4.29 \\
\hline Mills lambda $(\lambda)$ & $27.967 * * *$ & 10.895 & 2.57 \\
\hline Rho & 1 & & \\
\hline Sigma & 19.804 & 1.931 & \\
\hline Lambda & 19.804 & 1.931 & \\
\hline
\end{tabular}

Note: $* * * * *$ and $*$ shows significance at 1,5 and $10 \%$ respectively. 
Source: own computation from the survey result, 2020

Lagged market price: As expected lagged market price had positive and significant effects on potato marketed surplus at less than $1 \%$ significant level. Robust Heckman's second stage result shows that if the lagged market price for potato products was good the market surplus for potato products increased by 3.645Qt, making other variables constant. This indicates that if last year's prices for potato products were changed from bad to good most farmers facilitated to allocate large land for potato products and they supply a high amount of potato to the market. In the study area when compare potato supplied to the market in the lagged year with the survey year, there was a decrement in potato supplied to the market. This finding in line with Tadie and Lemma, (2018) who found that lagged market price has positive and significantly affect teff market participation

\subsubsection{Market outlet choice for potato producers'.}

In the model result Wald chi2(48) was significant at the $1 \%$ level, which indicates that the subset of coefficients of the model is jointly significant and that the explanatory power of the factors included in the model is satisfactory; thus, the MVP model fits the data reasonably well. Likewise, the model is significant because the null that the choice decision of the four potato market outlets is independent was rejected at a $1 \%$ significance level. The results of the likelihood ratio test in the model indicates the null that the independence between market outlet choice decision $(\rho 21=\rho 31=\rho 41=\rho 32=\rho 42=\rho 43=0)$ is rejected at $1 \%$ significance level and there are significant joint correlations for two estimated coefficients across the equations in the models.

There are differences in market outlet selection behavior among producers, which are reflected in the likelihood ratio statistics of the estimated correlation matrix shows that correlation between each pair of dependent variables $\rho 21$ (correlation between the choice for retailer and wholesaler outlet), $\rho 41$ (correlation between the choice for consumer and wholesaler outlet), $\rho 31$ (correlation between the choice for collectors and wholesaler outlet choice), and $\rho 32$ (correlation between the choice for collector and retailer outlet) are negative interdependent and significant at the $1,1,1$, and $5 \%$ probability levels respectively.

The simulated maximum likelihood (SML) estimation of marginal success probability for each outlet's result shows that the probability of potato producers' market outlets chooses wholesale, retailer, collector, and consumer was $36.54 \%, 54.48 \%, 25 \%$, and $37.18 \%$ respectively.

The result in Table 5 shows that out of 12 explanatory variables included in the multivariate probit model that can affect the market channel choice of potato in the district ten variables had a significant effect on market channel choice. They were the age of household head, educational level of household head, sex of household head, farm experiences, distance to near market, family size of household, remittance, land size allocated for potato, total product supplied to the market, own transport facility and frequency of extension service were found to significantly affect the market outlet choice behavior of potato producers. 
Table 5 Marginal effect after multivariate probit model estimation

\begin{tabular}{|c|c|c|c|c|}
\hline Variable & Wholesaler & Retailer & Collector & Consumer \\
\hline & $\mathrm{dF} / \mathrm{dx}$ & $\mathrm{dF} / \mathrm{dx}$ & $\mathrm{dF} / \mathrm{dx}$ & $\mathrm{dF} / \mathrm{dx}$ \\
\hline AGE & -.0011 & -.0082 & .0045 & $.0101^{*}$ \\
\hline EDUC & .0091 & .0033 & $-.0338 * *$ & $.0350^{* *}$ \\
\hline SEX & -.0306 & $.3618^{* *}$ & $-.2670 *$ & -.0644 \\
\hline COOP & -.0345 & .0631 & -.1149 & -.1298 \\
\hline FREXPR E & .0070 & -.00076 & $-.0141 * *$ & $-.0194 * *$ \\
\hline DNMARKET & .0014 & $-.0046 * *$ & -.00028 & .0043 \\
\hline Adultequ & .0069 & .0306 & $-.0379 *$ & .0388 \\
\hline REMITANCE & $.2337 * *$ & $-.3983 * * *$ & $.1575^{* *}$ & -.1378 \\
\hline Farm size allocated & -.0403 & .6241 & .0046 & .0226 \\
\hline Output supplied & $.0140 * * *$ & $-.0086 * *$ & -.00038 & -.0018 \\
\hline TRANOWN & -.2084 & $.3328 * * *$ & .0544 & $.2422 * *$ \\
\hline FXCON & -.0492 & .02213 & -.0177 & $.1387 * * *$ \\
\hline \multirow{2}{*}{\multicolumn{2}{|c|}{ Wald chi2(48) $=120.95^{* * *}$}} & \multicolumn{3}{|c|}{$\rho 21=\rho 31=\rho 41=\rho 32=\rho 42=\rho 43=0$} \\
\hline & & \multicolumn{3}{|c|}{$\begin{array}{l}\text { Log likelihood }=-285.080 \operatorname{chi} 2(6)= \\
48.592^{* * * *}\end{array}$} \\
\hline
\end{tabular}

Note: $* * *, * *$ and $*$ shows significance at 1,5 and $10 \%$ respectively.

Source: own computation from the survey result, 2020

Age of household head: The age of the farm household head affected choosing consumers market outlets positively and significantly at a $10 \%$ significant level. The result shows that the aged households are more likely to choose consumers' market outlets. This due to that, the older farmers did not travel too long distances to get other choices in the district market in addition to having a better knowledge of cost and benefits associated with various potato market outlets. 
The educational level of the farm household: household head had a positive and significant effect on market channel choice of a consumer at a 5\% significant level but negative effects on market channel choice of collectors at a 5\% significant level. The reason is that formal education enhances the information acquisition and adjustment abilities of the farmer, thereby improving the quality of decision-making on profitable and productive. This result is consistent with the findings of (Abreham, 2013; Addis et al, 2019)

Sex of household head: Sex of producer had negative and significant effects on collector channel choice at a $10 \%$ significant level. But it had a positive and significant effect on retailer channel choice at a 5\% significant level. This is due to the farm household head is female; they might have many duties in their family for that reason they may not select appropriate channels to sell their product. Therefore female household head simply sold their surplus product to a collector in the local area. And they decrease to sell for the retailer market outlet was higher compared to the male household head. This finding is related to Nuri, (2016) which found that male house farmers choose the best market outlets to sell their farm produce.

Farm experience on potato production: Farm experience in potato production affects market channel choice negatively and significantly for collector channel choice and consumer channel choice at a 5\% significant level respectively. This implies that making other things constant if the farm experience's on potato production increase by one year the probability of farm household head market channel choice for collector and consumer decreased by $1.41 \%$ and $1.94 \%$ respectively. The reason for this is because when farm household is more experienced and well known in potato production, he/she produce a huge amount of product and then they might choose another channel choice like wholesaler channel choice or retailer channel choice to sell a huge amount of products rather collector or consumer. Finding in line with Efa\&Tura, (2018) revealed that the experience of the producer had a positive effect on choosing market outlet choice.

Distance to the nearest market: It had a significant and negative effect on the decision of choosing the retailer market outlet at a 5\% significant level. The marginal effect result shows that all other things constant, the probability of choosing to retailer market outlet choice decreased by 0.46 percent to sell if the distances increase by one minute. This is since most producers prefer to sell their products at the farm gate without incurring transaction costs. Delivering potato products to the retailer mostly found in the town area to meet retailers, farm producers should pay transportation cost but they mightn't interest to pay. Therefore farm household heads select nearer markets, as well as farms, get channel choice for the potato product sell than retailers channel choice. This study is related to Bezabihet al., (2015) who found that distance to the market significantly affects market channel choice.

Family size (Adult equivalent): Household size has a negative and significant relationship with the likelihood of choosing collector outlets at less than a 5\% significant level. This result indicates that having more household size has a negative relation with likely choosing collector 
outlets. This finding is consistent with the finding of Takele et al, (2017) which found that having a large family size was better for delivering output to the final market outlet.

Remittance from farm household: It affects potato market outlets' choice. The model result shows that there is a positive effect of remittent on wholesaler and collector market outlet choice. But remittent has negative effects on retailers' market outlet choice. This is due to if there is/are family household members are remittent in other countries like South Africa, Dubai, etc. they send additional fund by that fund farm household head diversify their income into different types for that reason they are not willing to retail their product for that reason they choice wholesaler and collector outlet choice to sell potato product.

Quantity supplied to market: It influences market outlet choices significantly. For farm household head to select wholesaler market outlet choice positively affected by the quantity of potato supplied to the market at a $1 \%$ level of significance. And the likelihood of choosing retailers negatively and significantly by the quantity of potato supplied to the market at a $5 \%$ level of significance. The result shows households that supply large output of potato accessed wholesaler market outlet compared to households who supply less because of wholesaler capacity to purchase large amounts of potato products. This is because if the quantity of potato offered to the market is high producers' might fear taking it back to their house if it is not sold for that reason they choose wholesalers outlets. In another hand, if the amount of product that offered to the market is small, farm household might be interested to sell for retailers. This study is in line with Addisu, (2016). This finding shows that the household that chooses a wholesaler is positively and significantly affected by volume supply to the market.

Owning transport facilities: It influenced the choice of retailers and consumers outlets positively and significantly at $1 \%$ \& $10 \%$ significant level respectively. Transport facilities ownership by farmers increased the likelihood of choosing retailers and consumer outlets. This might be due to the reason that farmers who have their transport facilities could supply their products to urban centers and sell to retailers and consumers directly to get better prices than prices get from collectors/wholesalers. This shows that the availability of transportation facilities helps reduce long market distance constraints, offering greater depth in marketing choices. This result is in line with that of Tegegn, (2013) who found that owning transport facilities influenced the choice of retailer's outlet positively and significantly. Hussen, C.H., \&Fana, C. (2017) indicate that the more family size helps to supply vegetables to different retailer shops and restaurants in different units which affect operating vegetable production.

Frequency of extension contact: It affects market outlet choice for the potato market positively and significantly. The survey output indicates that the frequency of extension contact affects producers' consumer market outlet choice positively and significantly at less than $1 \%$ significant level. Farmers who have more access to extension improves household intellectual capital, which improves potato production, diverts production resources to markets rather than consumption, and choice market channels. The study conducted by Addis et al, (2019) on determinants of wheat market outlet choice of smallholder farmers: The case of Dembecha district, Amhara 
National Regional State, Ethiopia. They found that the frequency of extension contact affects consumers' market outlet choices positively.

\section{Conclusion and Recommendations \\ 4.1. Conclusion}

Results of Heckman's selection model indicated that the probabilities of potato market participation and the extent of potato market participation of the sample households were influenced by different factors. To this effect, the education level of household head, sex of household headed, membership in the cooperative, distance to the nearest market, remittent from family members, own transportation facilities, types of seed they used, frequency of extension contact, lagged market price and amount of credit used significantly affected the first binary decision of whether or not to participate in potato market. On the other hand, the education level of household head, being a membership on Cooperative, family size, total cropland have, oxen owned by a farmer, types of seed they used, lagged market price and inverse Milles ratio (LAMBDA) affected the second decision concerning farm households' extent of potato market participation.

Potato farmers in the study areas supply their products through different market outlets. Various factors affect their choices of potato market outlets. The channel alternatives in the potato value chain which are available to potato producers include collectors, wholesalers, retailers, and consumers.

The multivariate probit model was run to identify factors determining farmers' market outlet choice decision. The model results indicated that the probability to choose collectors' marketing outlet for potato was significantly affected by the educational level of the household head, sex of household head, farm experiences, family size of household, and remittance. Similarly, the probability of choosing wholesalers marketing outlet was affected by remittance and total product supplied to the market. The probability to choose retailers' market outlets was significantly affected by the sex of household head, distance to near market, remittance, total product supplied to the market, and access to own transport facility. The probability to choose consumers' market outlet was significantly affected by age of the household head, educational level, farm experiences, and access to own transport facility.

These problems can be addressed by providing improved seed, being membership in a cooperative, providing adult education, credit access, nearer market, income from remittance were very important.

\subsection{Recommendation}

The findings of this study enabled us to make the following recommendations for policymakers, development actors, and researchers who have a strong interest in promoting potato producers for making them benefiters in the market. 
Encouraging adult education for farmers is recommended by the concerning body; the government body, non-governmental institutions, and other concerning bodies should facilitate diversifying different cooperatives; improving rural infrastructure in developing market infrastructure in the form of establishing produce collection points across rural areas would assist poor farmers for faster delivery of farm products; credit-providing institutions should facilitate and give training on the use of credit for farmers, empowering women to exercise resource use rights and gains equal to males; office of agriculture, research institute, university; and different non-profit institutions should provide improved potato seeds for farmers; the concerning bodies should be trying to stop this informal labor trading system.

\section{Reference}

\section{REFERENCE}

Abduselam F., Zekarias S., and Mequanent M., (2018). Value chain analysis of Potato in Dedo district of Jimma zone, Ethiopia. Published at Journal of International Journal of Business Management and Technology, Volume 2, Issue 6, ISSN: 2581-3889

Abraham Tegegn. (2013). Value chain analysis of vegetables: Unpublished M.Sc. Thesis; Haramya University, Ethiopia.

Addis, Y., Tegegn, B., \& Mengistu, K. (2019). Value Chain Analysis of Wheat (Triticum Aestivum): The Case of Dembecha District, West Gojjam Zone, Ethiopia. Ethiopian Journal of Crop Science, 7(1), 77-91.

Addisu, H. (2016). Value chain analysis of vegetables: Unpublished M.Sc. Thesis; Haramya University, Ethiopia.

Bekele and Tadesse. (2019). Market chain analysis for potato. Journal of Economics and International Business Management Vol. 7(3), pp. 9-21, 2019.

Belayneh, Y. (2018). Review of Value Chain Analysis of Potato.Journal of Advances in Scientific Research and Engineering (ijasre), Volume 4, Issue 4.

BezabihEmana and HaderaGebremedihin, 2007. Constraints and opportunities of horticulture production and marketing in Eastern Ethiopia. Dry Lands Coordination Group Report No 46. Grensen 9b. Norway.

Christopher S, Johnny M, Enid K, Apolo K, Harriet K. (2014). Smallholder Farmers' Decision a nd Level of Participation in the Potato Market in Uganda. Modern Economy 5:895-906.

Efa, G. \& Tura, K. (2018). Determinants of Tomato Smallholder Farmers Market Outlet Choices in West Shewa, Ethiopia. Journal of Agricultural Economics and Rural Development, 4(2), 454-460, retrieved from www.premierpublishers.org,

Emana, B., Ketema, M., Mutimba, J. K., \& Yousuf, J. (2015). Factors affecting market outlet choice of potato producers in Eastern Hararghe Zone, Ethiopia. Journal of Economics and Sustainable Development, 6(15), 159-172. 
Endale G, Gebremedhin W, Berga L (2008). Potato Seed Management. In Root and tuber crops: Ethiopian Institute of Agricultural Research, Addis Ababa, Ethiopia. The untapped resources, ed. W. Gebremedhin, G. Endale, and B. Lemaga, 53- 78.

Gebru et al. (2017). Assessment of production practices of smallholder potato (Solanum tuberosum L.). Agric \& Food Secure 6.https://doi.org/10.1186/s40066-017-0106-8.

Habtamu G. (2015). Potatoes value chain analysis. Unpublished master's thesis, Haramaya University, Ethiopia.

Hussen, C.H., \& Fana, C. (2017). Determinants of Market outlet Choice for Major Vegetables Crop: Evidence from Smallholder Farmers' of Ambo and TokeKutaye Districts, West Shewa, Ethiopia.in SciRes. http://www.scirp.org/journal/me nhttp:/ /dx.doi.org/10.4236/me.2014.58082.

Nuri. L, Jema H, Endrias G, and Lemma. Z, (2016). Determinants of status and extent of Market Participation among kocho Producers in Hadiya Zone. International Journal of Agricultural Research and Review: ISSN-2360-7971, Vol. 4(2): pp. 476-485

Tadie Mirie1 and Lemma Zemedu. (2018). Teff market participation and intensity of participation. Journal of Development and Agricultural Economics, Vol. 10(10), pp. 359366.

Takele, H. Endrias, G. \& Amsalu, M.(2017). Determinants of Market Outlet Choice of The Smallholder Mango Producers: The Case of Boloso Bombe Woreda, Wolaita Zone, Southern Ethiopia: A Multivariate Probit Approach.Global Journal of Science Frontier Research, 17(2): 23-29

Yamane T (1967). Statistics: An Introductory Analysis, 2nd Edition. Harper and Row, Publisher, New York P 919. 


\section{Availability of Data and Material}

The datasets that support the findings of this study are available from the corresponding author on reasonable request.

\section{Competing Interest}

The author declared no competing interest.

\section{Funding}

The source of the fund was the Ministry of Science and Higher Education of Ethiopia.

\section{Authors' contributions}

The first author leads the overall research process and thoroughly revised all parts of the manuscript including abstract, introduction, methods, and interpretation of results. The second authors participated in primary data collection, analysis, and interpretation of preliminary results. All authors read and approved the final manuscript.

\section{Acknowledgments}

We author would like to thank the Ministry of Science and Higher Education of Ethiopia for financial support. Moreover, we would like to extend our deepest gratitude to those involved in respondents, enumerators, development agents, and experts in the district for their contribution to the data collection process of the study.

\section{Author Information}

Chaimiso Demisse1 Mebratu Alemu1* Afework Berihanu1* and Mesfin Melese1**

\section{Affiliations}

1. Department of Agricultural Economics, College of Agricultural Sciences, Arba Minch University, Arba Minch, Ethiopia 1* Department of Economics, College of Business and Economics, Arba Minch University, Arba Minch, Ethiopia 1**. Department of Agricultural Economics, College of Agricultural Sciences, Wolkite University, Ethiopia. 